\title{
Comparative studies of chitinases A and B from Serratia marcescens
}

\author{
May B. Brurberg, ${ }^{1,2}$ Ingolf F. Nes ${ }^{1}$ and Vincent G. H. Eijsink
}

Author for correspondence: May B. Brurberg. Tel: +4764949461 . Fax: +4764941465.

e-mail: mbruberg@bioslave.uio.no

1 Laboratory of Microbial Gene Technology,

Department of Biotechnological Sciences, Agricultural University of Norway, PO Box 5051, 1432 Ås, Norway

2 The Norwegian Crop Research Institute, As, Norway

\begin{abstract}
Serratia marcescens produces several chitinolytic enzymes, including chitinase $A$ (ChiA) and chitinase B (ChiB). In this study, ChiB was purified to homogeneity using a newly developed protocol based on hydrophobic interaction chromatography. Subsequently, characteristics of ChiB and of the hitherto only partly characterized ChiA were determined and compared. Pure ChiA and ChiB shared several characteristics such as a broad pH optimum around pH 5.0-6.0, and a temperature optimum between 50 and $60^{\circ} \mathrm{C}$. Both enzymes were fairly stable, with half-lives of more than $10 \mathrm{~d}$ at $37^{\circ} \mathrm{C}$, pH 6.1. Analyses of the degradation of various $\boldsymbol{N}$-acetylglucosamine oligomers, fluorogenic substrates and colloidal chitin showed that both enzymes cleave chitobiose [(GICNAC) ${ }_{2}$ ] from (GICNAC) ${ }_{n}$ and thus possess an exo-N,N'diacetylchitobiohydrolase activity. Both enzymes were also capable of

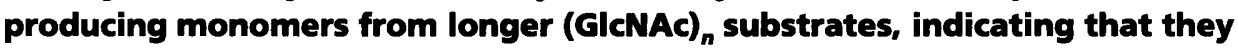
also have an endochitinase (ChiA) or exo- $N, N^{\prime}, N^{\prime}$-triacetylchitotriohydrolase (ChiB) activity. Kinetic analyses with 4-methylumbelliferyl- $\beta-D-N, N$ diacetylchitobioside, an analogue of (GICNAC) ${ }_{3}$, showed cooperative kinetics for ChiA, whereas for ChiB normal hyperbolic kinetics were observed. ChiA had a higher specific activity towards chitin than $\mathrm{ChiB}$ and synergistic effects on the chitin degradation rate were observed upon combining the two enzymes. These results, together with the results of sequence comparisons and previous studies of the cellular localization of the two chitinases in S. marcescens indicate possible roles for ChiA and ChiB in chitin breakdown.
\end{abstract}

Keywords: chitinase, Serratia marcescens, chitin, chitobiosidase

\section{INTRODUCTION}

Several bacteria and fungi are capable of enzymic degradation of chitin, the $(1 \rightarrow 4)$ - $\beta$-linked polymer of $N$-acetyl$\beta$-D-glucosamine (GlcNAc), for autolytic, morphogenetic or nutritional purposes (Gooday, 1990). Since chitin is a major structural component of fungal cell walls, chitinolytic enzymes could in principle be employed as natural anti-fungal agents and are therefore of biotechnological importance (Shapira et al., 1989; Schickler et al., 1993; Lorito et al., 1994). The conversion of chitin to GlcNAc involves several hydrolases. Chitinases (EC 3.2.1.14), also called endochitinases, cleave glycosidic linkages

\footnotetext{
Abbreviations: ChiA, chitinase A from S. marcescens; ChiB, chitinase B from S. marcescens; GIcNAC, $N$-acetylglucosamine; 4-MU, 4methylumbelliferyl; 4-MU-(GICNAc), 4-methylumbelliferyl $N$-acetyl- $\beta$-Dglucosaminide; 4-MU-(GICNAC) ${ }_{2}$, 4-methylumbelliferyl $\beta$-o- $N, N^{\prime}$ diacetylchitobioside; 4-MU-(GICNAC) ${ }_{3}$, 4-methylumbelliferyl $\beta-\mathrm{D}-N_{,}, N^{\prime}, N^{\prime \prime}$ triacetylchitotriose; [S], substrate concentration.
}

randomly along the chitin chain, eventually producing short oligomers of GlcNAc (Monreal \& Reese, 1969; Robbins et al., 1988; Roberts \& Selitrennikoff, 1988; De la Cruz et al., 1992). Exo- $N, N^{\prime}$-diacetylchitobiohydrolases, also called exochitinases or chitobiosidases, cleave off chitobiose (GlcNAc), from the non-reducing end of (GlcNAc) ${ }_{n}$ (Davis \& Eveleigh, 1984; Robbins et al., 1988; Tronsmo \& Harman, 1993). Finally, $N$-acetyl$\beta$-glucosaminidases (EC 3.2.1.52) cleave off GlcNAc monomers from the non-reducing ends of chitobiose and higher analogues (Monreal \& Reese, 1969; Robbins et al., 1988).

Serratia marcescens, a Gram-negative bacterium belonging to the family Enterobacteriaceae, is one of the most efficient bacteria for degradation of chitin (Monreal \& Reese, 1969; Schickler et al., 1993). It may produce up to five different chitinolytic enzymes upon induction with chitin (Fuchs et al., 1986). The best known of these is the secreted chitinase A (ChiA), the three-dimensional struc- 
ture of which has been described (Perrakis et al., 1994). However, knowledge of the enzymic properties of ChiA is very limited (Monreal \& Reese, 1969; Roberts \& Cabib, 1982; Roberts \& Selitrennikoff, 1988; Vorgias et al., 1993) and most of this knowledge is derived from studies with partly purified enzyme preparations containing an incompletely defined mixture of chitinases (Monreal \& Reese, 1969; Roberts \& Cabib, 1982). Genes encoding ChiA have been isolated from various strains of $S$. marcescens, and their nucleotide sequences have been determined (Jones et al., 1986; Koo et al., 1993; Brurberg et al., 1994). Harpster \& Dunsmuir (1989) and Brurberg $e t$ al. (1995) have described two almost identical S. marcescens genes encoding a periplasmic chitinolytic enzyme, called chitinase $\mathrm{B}(\mathrm{ChiB})$. Little is known about the properties of the latter enzyme and its purification has not been described. ChiA $\left(M_{\mathrm{r}} 58514\right)$ and $\mathrm{ChiB}\left(M_{\mathrm{r}} 55469\right)$ share $32 \%$ sequence identity (Brurberg et al., 1994, 1995). Both enzymes are able to inhibit fungal growth under some conditions (Sundheim et al., 1988; Shapira et al., 1989; Schickler et al., 1993).

Apart from a few characteristics of ChiA, little is known about the properties of the individual $S$. marcescens chitinases. The present report describes a detailed study of ChiA and ChiB produced by $S$. marcescens BJL200 (Sundheim et al., 1988). This study was conducted to elucidate the individual roles of $\mathrm{ChiA}$ and $\mathrm{ChiB}$ in the degradatory pathway for chitin and, furthermore, to determine general enzyme characteristics, such as stability and catalytic properties, that could be of importance for the application of these enzymes. ChiA and $\mathrm{ChiB}$ were purified from recombinant Escherichia coli strains overexpressing the previously cloned chi $A$ (Brurberg $e t$ al., 1994) and $c h i B$ (Brurberg et al., 1995) genes. Since the purification of $\mathrm{ChiB}$ had not been described previously, an efficient protocol for the purification of this enzyme was developed.

\section{METHODS}

Purification of the chitinases. ChiA and $\mathrm{ChiB}$ were purified from periplasmic extracts of early stationary phase cultures of $E$. coli harbouring plasmid pMAY20-1 (Brurberg et al., 1994) and E. coli harbouring plasmid pMAY2-10 (Brurberg et al., 1995), respectively. The extracts were prepared by osmotic shock, as described by Manoil \& Beckwith (1986). The volume of the periplasmic extracts was one-tenth of the volume of the original culture.

All chromatographic media, columns and equipment were supplied by Pharmacia-LKB. The purification of ChiA has been described elsewhere (Brurberg et al., 1994). In the optimized purification procedure for $\mathrm{ChiB}$, the periplasmic extract (in $0.65 \mathrm{mM} \mathrm{MgCl}, 0.1 \mathrm{mM}$ PMSF, $1 \mathrm{mM}$ EDTA) was diluted 1.4-fold and adjusted to $20 \mathrm{mM}$ Tris/ $\mathrm{HCl}, \mathrm{pH} 8.0$ and $0.4 \mathrm{M}$ ammonium sulphate. From this dilution, $2 \mathrm{ml}$ was loaded onto a Phenyl-Superose HR $5 / 5$ column $(5 \times 50 \mathrm{~mm})$ in an FPLC system, equilibrated in buffer A $(20 \mathrm{mM}$ Tris/ $\mathrm{HCl}, \mathrm{pH} 8.0$, $1 \mathrm{mM}$ EDTA, $0.1 \mathrm{mM}$ PMSF) containing $0.4 \mathrm{M}$ ammonium sulphate. After loading the sample, the column was washed with the starting buffer followed by a $5 \mathrm{ml}$ linear gradient of $0.4-0 \mathrm{M}$ ammonium sulphate. Subsequently, a linear gradient of $0-6 \%$ $(\mathrm{v} / \mathrm{v})$ 2-propanol was applied (see Fig. 1). The same purification procedure could also be performed successfully using a volatile

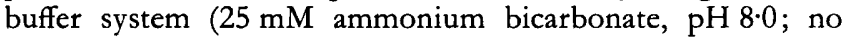
addition of PMSF and EDTA).

Enzyme purity was verified by SDS-PAGE, essentially according to Laemmli (1970). The gels were stained with Coomassie brilliant blue G-250. The purified enzymes were identified by $\mathrm{N}$-terminal amino acid sequencing, using an Applied Biosystems automatic sequenator, model 477A.

Enzyme assays. Chitinolytic activity was determined using the (GlcNAc) $)_{3}$, analogue 4-methylumbelliferyl- $\beta$-D- $N, N^{\prime}$-diacetylchitobioside [4-MU-(GlcNAc) ${ }_{2}$; Sigma; Kuranda \& Robbins, 1987]. Standard reactions mixtures contained $69 \mu \mathrm{M} 4-\mathrm{MU}-$ (GlcNAc), $0 \cdot 1 \mathrm{mg} \mathrm{ml}^{-1}$ purified BSA (New England Biolabs) and the enzyme, in $50 \mathrm{mM}$ citrate phosphate buffer, $\mathrm{pH} 6.1$ (Stoll \& Blanchard, 1990). The reaction mixture (total volume $100 \mu \mathrm{l}$ ) was incubated at $37^{\circ} \mathrm{C}$ for $10 \mathrm{~min}$, after which the reaction was stopped by adding $1.9 \mathrm{ml} 0.2 \mathrm{M} \mathrm{Na}_{2} \mathrm{CO}_{3}$. The product formation was linear with time during the reaction. The 4-methylumbelliferone (4-MU) moiety is fluorescent when it becomes ionized above $\mathrm{pH} 8$ and after excitation at $380 \mathrm{~nm}, 4-$ MU emits at a wavelength of $460 \mathrm{~nm}$. The amount of 4-MU released was determined with a TKO 100 Mini Fluorimeter using a 4-MU solution as standard (Hoefer Scientific Instruments). The activities were determined as the mean of at least three independent measurements and expressed as the amount of 4-MU released $\mathrm{min}^{-1}$. Standard deviations were less than $3 \%$ of the means in all cases.

Activity towards 4-MU-GlcNAc and 4-MU-(GlcNAc) 3 was determined using the same conditions as for 4-MU-(GluNAc) ${ }_{2}$. Cleavage of 4-MU-(GlcNAc) $)_{3}$ into (GlcNAc) ${ }_{2}$ and 4-MUGlcNAc (undetectable) was monitored by measuring the amount of substrate remaining after the incubation. The substrate was measured by adding excess purified ChiA, which converts 4-MU-(GlcNAc) $)_{3}$ almost exclusively into 4-MU and GlcNAc mono- and oligomers (see Results).

Variation in the $\mathrm{pH}$ in the assays was achieved by replacing the standard $\mathrm{pH} 6.1$ buffer with the following buffers $(50 \mathrm{mM})$ :

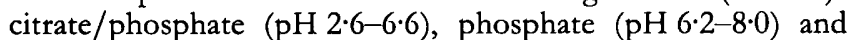
Tris $/ \mathrm{HCl}(\mathrm{pH} \mathrm{7 \cdot 6-8 \cdot 8)} \mathrm{(Stoll} \mathrm{\&} \mathrm{Blanchard,} \mathrm{1990).} \mathrm{The} \mathrm{standard}$ $\mathrm{pH} 6.1$ citrate/phosphate buffer was replaced by $50 \mathrm{mM} \mathrm{MES}$, $\mathrm{pH} 6 \cdot 1$, in reaction mixtures containing metal ions.

Kinetic properties were determined by initial rate measurements at various $4-\mathrm{MU}-(\mathrm{GlcNAc})_{2}$ concentrations using the standard assay conditions described above, except for a larger reaction volume. Reactions were initated by the addition of the enzyme to a final concentration of $0.19 \mathrm{nM}$ or $0.67 \mathrm{nM}$, for ChiA and $\mathrm{ChiB}$, respectively. Product formation was monitored by measuring fluorescence in $100 \mu \mathrm{l}$ samples that were transferred from the reaction mixture to $1.9 \mathrm{ml} 0.2 \mathrm{M} \mathrm{Na}_{2} \mathrm{CO}_{3}$ at different time points. Under these conditions product formation was linear with time for at least $10 \mathrm{~min}$, at all substrate concentrations used. Initial rates $(v)$ were determined using at least six time points within the first $10 \mathrm{~min}$ after adding the enzyme to the reaction mixture. All product formation curves obtained by linear regression had correlation coefficients over 0.999. Where appropriate, the data were fitted to the Michaelis-Menten model, using a program minimizing deviations in $\log v$ (cf. Cleland, 1963).

Protein concentrations were determined by the method of Bradford (1976), using BSA as a standard.

Analysis of hydrolysis products of GICNAC oligomers and chitin. ChiA $\left(15 \mu \mathrm{g} \mathrm{ml}^{-1}\right)$ and $\mathrm{ChiB}\left(10 \mu \mathrm{g} \mathrm{ml}^{-1}\right)$ were incubated for various times with $2-4 \mathrm{mg}$ of a GlcNAc oligomer $\mathrm{ml}^{-1}$ [(GlcNAc) ${ }_{1-6}$; Seikagaku Kogyo Co.; Sigma] in $50 \mathrm{mM}$ citrate/ 
phosphate buffer ( $\mathrm{pH} 6.1$ ), at $37^{\circ} \mathrm{C}$. The hydrolysis products were separated by TLC using a silica gel 60 plate (Merck) and a solvent system of 1-butanol/ethanol/water $(5: 3: 2$, by vol.) (John et al., 1993). Sugars were detected by spraying with a diphenylamine/aniline/orthophosphoric acid reagent (Walkley \& Tillman, 1977).

Colloidal chitin was prepared according to Vessey \& Pegg (1973) and used as a substrate for the chitinases. The enzymes were incubated at $37^{\circ} \mathrm{C}$ with $0.19 \mathrm{mg}$ chitin $\mathrm{ml}^{-1}$, in $50 \mathrm{mM}$ citrate/phosphate buffer ( $\mathrm{pH} \mathrm{6.1}$ ), $0 \cdot 1 \mathrm{mg} \mathrm{BSA} \mathrm{ml}^{-1}$. The reaction was followed by determining the turbidity of the chitin suspensions at $410 \mathrm{~nm}$. The release of reducing groups was determined using the method described by Imoto \& Yagishita (1971).

\section{RESULTS}

\section{Purification of ChiA and ChiB}

Several chromatographic methods were tested for the purification of ChiB from periplasmic extracts of E. coli harbouring pMAY2-10. Cation and anion exchange appeared not to be suitable, since no satisfactory binding

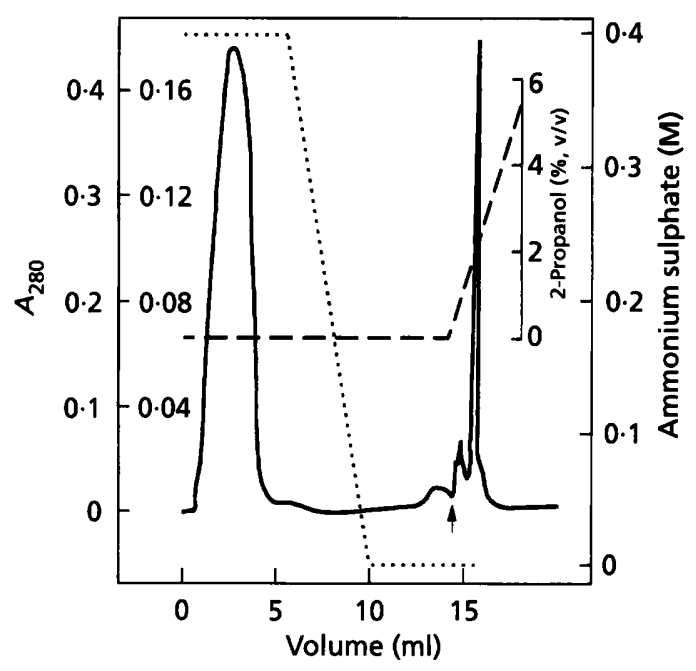

Fig. 1. Purification of ChiB. Hydrophobic interaction chromatography was performed as described in Methods. At the point indicated by the arrow, the sensitivity of the UV detector was increased by a factor of $2 \cdot 5$. Chitinase activity was only detected in the peak at $16 \mathrm{ml}$ -,$A_{280} ; \ldots .$. , ammonium sulphate concentration; ---, 2-propanol concentration.

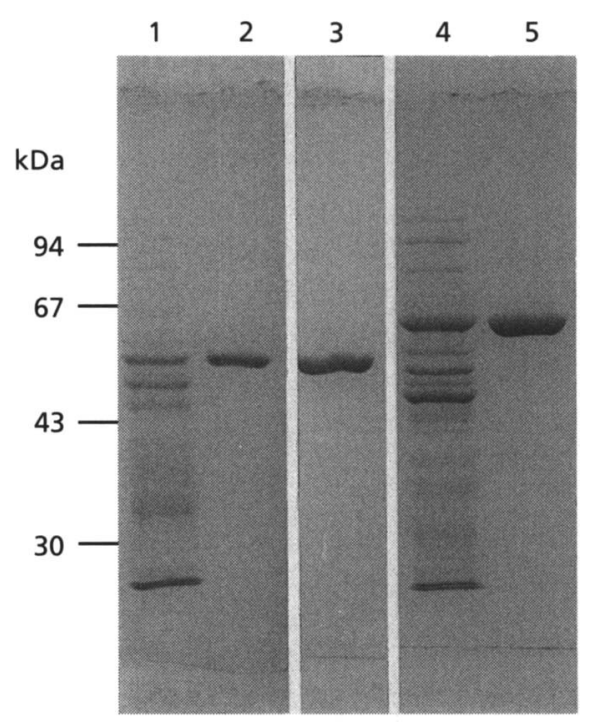

Fig. 2. SDS-PAGE analysis of purified ChiB and ChiA. Lanes 1-3, ChiB; lanes 4 and 5, ChiA. Lane 1, undiluted periplasmic extract of $E$. coli harbouring pMAY2-10; lane 2, purified ChiB: lane 3, fraction corresponding to that in lane 2, but obtained after hydrophobic interaction chromatography using a $25 \mathrm{mM}$ ammonium bicarbonate buffer, followed by concentration by freeze-drying; lane 4, undiluted periplasmic extract of $E$. coli harbouring pMAY20-1; lane 5, purified ChiA. The approximate positions of marker proteins are indicated.

of chitinolytic activity to SP-Sepharose ( $\mathrm{pH}$ tested $5 \cdot 0-6 \cdot 9)$ or Q-Sepharose ( $\mathrm{pH}$ tested) 6.9-8.9) was obtained. ChiB adsorbed efficiently to Phenyl-Sepharose CL-4B at low concentrations of ammonium sulphate and therefore a hydrophobic interaction chromatography protocol was developed. Fig. 1 shows the elution profile obtained using the optimized conditions for hydrophobic interaction chromatography described in Methods. All chitinase activity adsorbed to the column and was eluted as a sharp peak at $16 \mathrm{ml}$ (Fig. 1). A typical experiment yielded $70-90 \mu \mathrm{g}$ chitinase, the recovery of enzyme activity being over $90 \%$ (Table 1). SDS-PAGE analysis (Fig. 2) showed that the peak fractions contained highly pure protein, with an $M_{\mathrm{r}}$ in good agreement with that predicted from the sequence of the chiB gene (55469; Brurberg et al., 1995). Similar results were obtained when a volatile buffer system was used (Fig. 2, lane 3). ChiA was purified as described previously (Brurberg et al., 1994) and the

Table 1. One-step purification of ChiB by hydrophobic interaction chromatography

\begin{tabular}{|c|c|c|c|c|c|}
\hline & $\begin{array}{c}\text { Volume } \\
(\mu 1)\end{array}$ & $\begin{array}{c}\text { Total } \\
\text { protein } \\
(\mu g)\end{array}$ & $\begin{array}{c}\text { Total } \\
\text { activity* } \\
\left(\mathrm{nmol} \mathrm{s}^{-1}\right)\end{array}$ & $\begin{array}{c}\text { Recovery } \\
\text { of activity } \\
(\%)\end{array}$ & $\begin{array}{c}\text { Specific } \\
\text { activity } \\
\left(\mathrm{nmol} \mathrm{s}^{-1} \mathrm{mg}^{-1}\right)\end{array}$ \\
\hline Diluted periplasmic extract & 2000 & 955 & $11 \cdot 7$ & 100 & $12 \cdot 3$ \\
\hline Peak fractions & 620 & 78 & $11 \cdot 2$ & 96 & 144 \\
\hline
\end{tabular}

* Chitinase activity is expressed as the amount of 4-MU released per unit of time; standard deviations in the activity measurements did not exceed $3 \%$ of the means $(n=3)$. 
identities of purified $\mathrm{ChiA}$ and $\mathrm{ChiB}$ were confirmed by $\mathrm{N}$-terminal amino acid sequencing.

\section{Optimal conditions for enzyme action}

At the standard assay temperature of $37^{\circ} \mathrm{C}$, both ChiA and $\mathrm{ChiB}$ were active towards $4-\mathrm{MU}-(\mathrm{GlcNAc})_{2}$ in a broad $\mathrm{pH}$ range, with maximum activity occurring between $\mathrm{pH} 5.0$ and $\mathrm{pH} 6.0$. The enzymes retained $50 \%$ of their activity in a broad $\mathrm{pH}$ range $(3 \cdot 5-8 \cdot 4$ for ChiA and 3.2-8.2 for ChiB). At $\mathrm{pH} 6 \cdot 1$, maximum activity occurred at temperatures between 50 and $60^{\circ} \mathrm{C}$, the optima being 54 and $58{ }^{\circ} \mathrm{C}$, for $\mathrm{ChiA}$ and $\mathrm{ChiB}$, respectively. At least $50 \%$ of the maximum activity of $\mathrm{ChiA}$ and $\mathrm{ChiB}$ was obtained at $39-62{ }^{\circ} \mathrm{C}$ and $46-66^{\circ} \mathrm{C}$, respectively.

Under standard assay conditions $\left(37^{\circ} \mathrm{C}, \mathrm{pH} 6.1\right)$ the activity of ChiA and $\mathrm{ChiB}$ was not affected by the presence of $10 \mathrm{mM}$ divalent metal ions $\left(\mathrm{MgCl}_{2}, \mathrm{CaCl}_{2}, \mathrm{CoCl}_{2}\right.$, $\mathrm{CuSO}_{4}$ and $\mathrm{MnCl}_{2}$ were tested), nor by the presence of $20 \mathrm{mM}$ EDTA. The activity of both enzymes was reduced by more than $99 \%$ in the presence of $10 \mathrm{mM} \mathrm{AgNO}$. Varying the $\mathrm{NaCl}$ concentration in the reaction mixtures from 0 to $0.5 \mathrm{M}$ did not result in changes in activity. ChiA activity was reduced to $30 \%$ in the presence of $1.2 \mathrm{mM}$ $(\mathrm{GlcNAc})_{2}$. Under the same conditions, ChiB displayed $91 \%$ activity.

\section{Enzyme stability}

Purified chitinases $\left[50-200 \mu \mathrm{g} \mathrm{ml}^{-1}\right.$, in elution buffer: $20 \mathrm{mM}$ Tris/HCl, pH 8.0, $1 \mathrm{mM}$ EDTA, $0 \cdot 1 \mathrm{mM}$ PMSF, $2-4 \%(\mathrm{v} / \mathrm{v}) 2$-propanol] could be stored at $4{ }^{\circ} \mathrm{C}$ for several months without significant loss of activity. After dilution to working concentrations $\left(0 \cdot 1-2 \mu \mathrm{g} \mathrm{ml}^{-1}\right.$, $\mathrm{pH}$ 6.1) a rapid loss of activity was observed, which could be prevented by the addition of $0.1 \mathrm{mg} \mathrm{BSA} \mathrm{m}{ }^{-1}$ to the dilution buffer. Therefore, all solutions used for assaying enzyme activity in this study contained $0 \cdot 1 \mathrm{mg} \mathrm{BSA} \mathrm{m}^{-1}$.

Thermal inactivation experiments showed that ChiA and $\mathrm{ChiB}$ were quite stable at $\mathrm{pH} 6 \cdot 1$, but at temperatures over $50^{\circ} \mathrm{C}$ stability was reduced considerably. ChiA was the more stable of the two chitinases, its half-life being 5-10fold higher than that of $\mathrm{ChiB}$ at temperatures between 48 and $54^{\circ} \mathrm{C}$. At $37^{\circ} \mathrm{C}$, the half-lives of $\mathrm{ChiA}$ and $\mathrm{ChiB}$ were $>400 \mathrm{~h}$ and $280 \mathrm{~h}$, respectively.

\section{Degradation of GlcNAC oligomers, synthetic substrates and chitin}

Analyses of the cleavage of (GlcNAc) $)_{1-6}$ showed that both $\mathrm{ChiA}$ and $\mathrm{ChiB}$ convert (GlcNAc) $)_{3-6}$ into $(\mathrm{GlcNAc})_{2}$ or into a mixture of (GlcNAc) ${ }_{2}$ and GlcNAc, depending on the substrate (Fig. 3), but do not digest (GlcNAc) ${ }_{2}$. ChiA exclusively cleaved (GlcNAc) ${ }_{2}$ from the substrates, as shown by the lack of GlcNAc and (GlcNAc) ${ }_{3}$ in both the partial and the complete digestion patterns obtained with $(\mathrm{GlcNAc})_{4}$ and $(\mathrm{GlcNAc})_{6}$ as substrates (Fig. 3a, c). Figs 3(b) and 3(d) show that $\mathrm{ChiB}$ also primarily produced (GlcNAc) ${ }_{2}$ from the substrates. However, as shown by the faint spots at the (GlcNAc) ${ }_{3}$ position in Fig. 3(d), lane
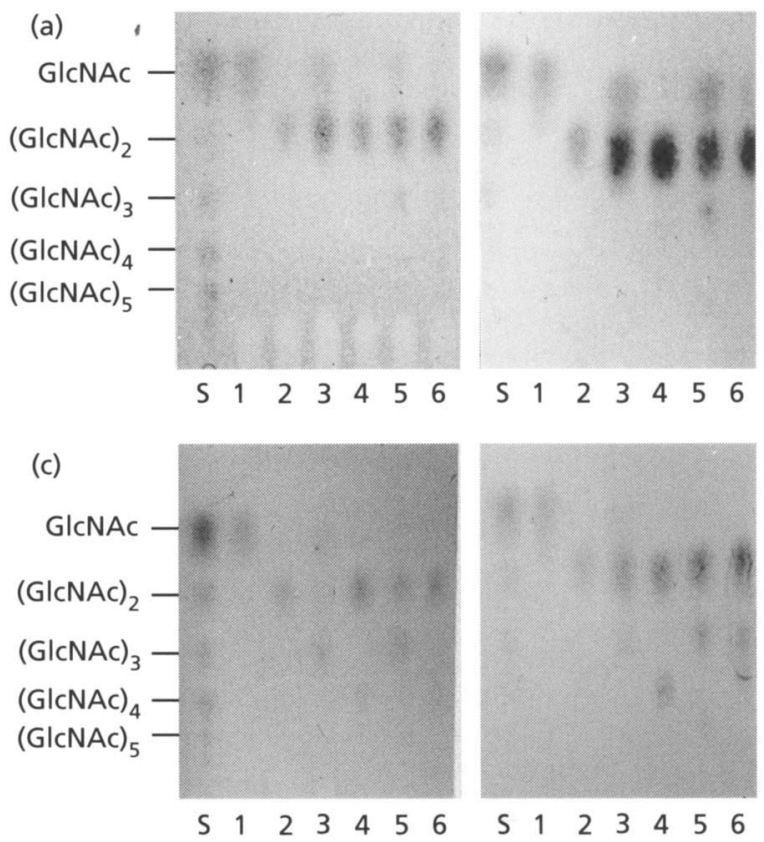

(d)

Fig. 3. Degradation of GlCNAC oligomers. Digestion products were analysed by TLC. Lanes 1-6 contain the digestion products obtained after incubating ChiA or ChiB with the mono- to hexamer of GICNAC, respectively. The lanes labelled $S$ contain a mixture of undigested GICNAC oligomers. The positions of the respective oligomers are indicated on the left. (a) ChiA, full digest ( $3 \mathrm{~h}$ incubation); (b) ChiB, full digest $(3 \mathrm{~h}) ;(\mathrm{c}) \mathrm{ChiA}$, representative example of a partial digest; (d) ChiB, representative example of a partial digest.

6, and the GlcNAc position in Fig. 3(b), lane 6, ChiB also cleaved (GlcNAc) $)_{6}$ into (GlcNAc) ${ }_{3}$ [subsequently converted into (GlcNAc) ${ }_{2}$ and GlcNAc]. GlcNAc and $(\mathrm{GlcNAc})_{3}$ were not detectable at any stage of the reaction of $\mathrm{ChiB}$ with (GlcNAc) . $_{\text {. }}$

Neither ChiA nor $\mathrm{ChiB}$ released 4-MU from the (GlcNAc) ${ }_{2}$ analogue 4-MU-GlcNAc, confirming the conclusion from the TLC analyses above that neither of the enzymes was capable of converting (GlcNAc) $)_{2}$ into monomers. Upon incubation of ChiA with the (GlcNAc) ${ }_{4}$ analogue 4-MU-(GlcNAc) $)_{3}$, more than $98 \%$ of the substrate was converted into 4-MU plus GlcNAc monoand oligomers. 4-MU was released at a rate comparable to that of the conversion of 4-MU-(GlcNAc $)_{2}$. In contrast to ChiA, ChiB did not release 4-MU from 4-MU-(GlcNAc) but converted it into $(\mathrm{GlcNAc})_{2}$ plus the non-fluorogenic 4-MU-GlcNAc, at a rate that was approximately 10 -fold higher than its rate of conversion of 4-MU-(GlcNAc) $)_{2}$.

TLC analysis of the digestion products of colloidal chitin showed that both ChiA and ChiB degrade chitin to (GlcNAc) ${ }_{2}$ and a minor fraction of GlcNAc (results not shown). Differences between ChiA and ChiB in terms of reaction products seen in TLC analysis were not detectable at any stage of the reactions. Furthermore the ratio between the decrease in turbidity of the chitin suspension and the release of reducing groups was approximately the 
Table 2. Degradation of chitin by ChiA and ChiB

The indicated amounts of enzyme were incubated with colloidal chitin in a total volume of $1 \mathrm{ml}$ for $24 \mathrm{~h}$ at $37^{\circ} \mathrm{C}$, as described in Methods. Chitin degradation is expressed as the percentage reduction in turbidity of the reaction mixture. Values are means \pm SD for three determinations.

\begin{tabular}{|lc|}
\hline Enzyme & $\begin{array}{c}\text { Degradation } \\
\text { (\%) }\end{array}$ \\
\hline ChiA $(1.8 \mu \mathrm{g})$ & $26 \pm 2.2$ \\
ChiA $(3.6 \mu \mathrm{g})$ & $36 \pm 2.3$ \\
ChiB $(1.8 \mu \mathrm{g})$ & $16 \pm 3.6$ \\
ChiB $(3.6 \mu \mathrm{g})$ & $21 \pm 1.9$ \\
ChiA $(1.8 \mu \mathrm{g})+\mathrm{ChiB}(1.8 \mu \mathrm{g})$ & $65 \pm 3.7$ \\
\hline
\end{tabular}

same for both enzymes (differences in this ratio could indicate differences between the exo/endo character of the enzymes; Tronsmo \& Harman, 1993). In contrast with this apparent similarity of the two enzymes, clear synergistic effects on the rate of degradation of chitin were observed when ChiA and ChiB were combined (Table 2). Consequently, the two chitinases must differ in the way they contribute to the degradation of chitin, as already indicated by the differences observed with synthetic substrates and GlcNAc oligomers (see above). Another difference between the two enzymes is illustrated by the fact that ChiA has a higher specific activity towards chitin than has ChiB (Table 2).

\section{Kinetic properties}

The assay for chitinolytic activity with the (GlcNAc) ${ }_{3}$ analogue 4-MU-(GlcNAc $)_{2}$ is sensitive and reliable, and permitted detailed kinetic analyses. As illustrated by Fig. 4 , both chitinases were inhibited at high concentrations of the substrate. At the lower substrate concentrations, ChiA exhibited sigmoid kinetics, indicating cooperativity (Fig. $4 a)$, whereas ChiB displayed a normal hyperbolic relationship between the rate of catalysis, $\nu$, and substrate concentration, [S] (Fig. 4b). Kinetic parameters for ChiB were approximated using eight points at low substrate concentration $(1.5-8 \mu \mathrm{M})$, resulting in a $K_{\mathrm{m}}$ of $34 \cdot 1 \pm 1 \cdot 4 \mu \mathrm{M}$ and a $k_{\text {cat }}$ of $19 \cdot 1 \pm 0 \cdot 7 \mathrm{~s}^{-1}$.

The occurrence of substrate inhibition by an unknown mechanism prevented quantitative analysis of the sigmoid kinetics observed for ChiA. In an attempt to approximate kinetic parameters for $\mathrm{ChiA}$, possible values for the apparent Hill coefficient $(b)$ were tested by analysing the linearity and the distribution of residual errors in adapted Lineweaver-Burk plots $\left(1 / v\right.$ versus $1 /[\mathrm{S}]^{n}$, for [S] $<12 \mu \mathrm{M}$; Segel, 1975). This approach indicated an $b$ in the range $1 \cdot 1-1 \cdot 2$. If $b$ is known, $[S]_{0.5}$ ([S] at which $v=0.5 V_{\max }$ ) and $V_{\max }$ can be derived from the $v$ and [S] values belonging to the maximum in the Eadie-Scatchard plot (Segel, 1975). The maximum in the Eadie-Scatchard plot (Fig. 4a) occurs at $[\mathrm{S}]=26 \mu \mathrm{M}, \nu=13.59 \mathrm{~s}^{-1}$,
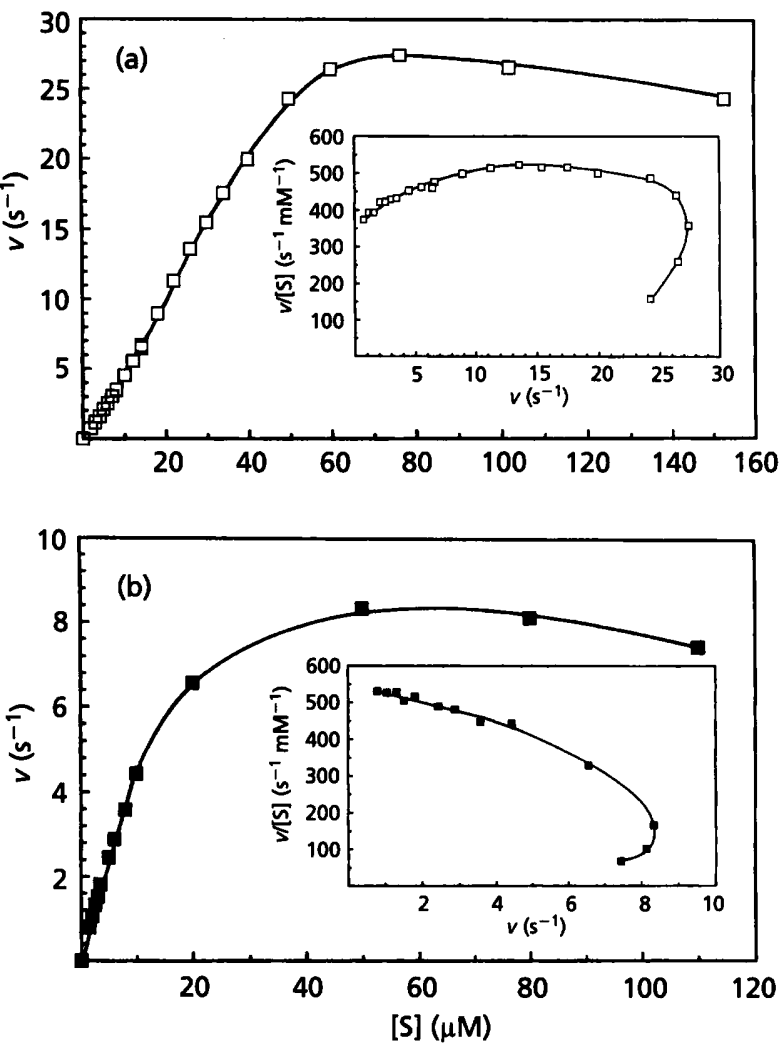

Fig. 4. Kinetic analysis. The main graph shows the dependence of initial velocity (v) on substrate concentration ([S]) in the reaction of ChiA (a) or ChiB (b) with 4-MU-(GICNAC) 2 . Enzyme concentrations were $0.19 \mathrm{nM}$ and $0.67 \mathrm{nM}$, for ChiA and ChiB, respectively. The inserts show Eadie-Scatchard plots derived from the $v$ versus [S] curves; the lines in these plots were drawn for illustration purposes only and connect the points in order of increasing [S], starting at the points close to the $v /[S]$ axis. Both enzymes are inhibited at high substrate concentrations. The curvature in the left part of the Eadie-Scatchard plot in (a) indicates cooperative kinetics for ChiA. The accuracy of these measurements is discussed in Results.

$v /[\mathrm{S}]=523 \mathrm{~s}^{-1} \mathrm{nM}^{-1}$, which, assuming an $b$ of $1 \cdot 15$, results in $[\mathrm{S}]_{0.5}=135 \mu \mathrm{M}$ and $k_{\text {cat }}=104 \mathrm{~s}^{-1}$. The values for $[S]_{0 \cdot 5}$ and $k_{\text {cat }}$ derived from the Eadie-Scatchard plot are an underestimation of the real values, since substrate inhibition lowers the $v$ and [S] values at which the maximum in this plot occurs.

\section{Sequence comparisons}

Several authors have pointed out that prokaryotic chitinases are built up of regions (domains) that are recognizable by sequence similarities. Such regions are the signal sequence, the catalytic domain, the chitin-binding domain, and the so-called fibronectin type III-like domain (Bork \& Doolittle, 1992; Watanabe et al., 1993, 1994; Blaak et al., 1993). The chitin-binding domain and the fibronectin type III-like domains are important for activity towards chitin (Watanabe et al., 1994). Blaak et al. (1993) concluded that $\mathrm{ChiB}$ consists of a catalytic domain and a C-terminal domain of approximately 60 residues that 
(a)

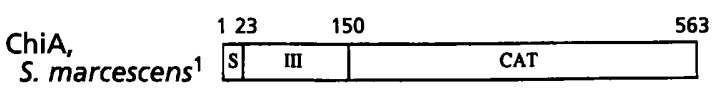

\begin{tabular}{|c|c|c|c|c|c|}
\hline & & & 499 & & \\
\hline $\begin{array}{l}\text { C. marcescens }{ }^{2} \\
\text { S. marces }\end{array}$ & & CAT & $\mathrm{CH}$ & & \\
\hline & 132 & & 458 & 552 & 647699 \\
\hline B. circulans 3 & $\mathbf{s}$ & CAT & III & & $\mathrm{CH}$ \\
\hline
\end{tabular}

(b)

ChiA, S. marcescens ${ }^{1}$ ChiB, S. marcescens Chitinase A1, B. circulans ${ }^{3}$ Chitinase D, B. circulans ${ }^{4}$ Chitinase II, Aeromonas sp. ${ }^{5}$

409 APATKPDTAYTTVNGVNALLA 429 453 APAYVPGTTYAOGAIVSYQGY 473 653 TSAmQVirat 31 AAQWQAGTAYKQGDLVTYLNR 51 494 CAAWAEGNTYTAGTCASYGGX 514

Fig. 5. Domains in bacterial chitinases. (a), Domains recognizable by sequence and/or structural similarities are indicated as follows: CAT, catalytic domain; $S$, signal sequence; $\mathrm{CH}$, chitin-binding domain; III, fibronectin type III-like domain. Residue numbers refer to the numbering of the primary gene product (including the signal sequence). The possible chitinbinding sequence present in the catalytic domain of ChiA is not indicated (see b). It should be noted that ChiB has no signal sequence and is not processed at the $\mathrm{N}$-terminus, despite the fact that it is exported to the periplasm (Brurberg et al., 1995). (b) Sequence alignment of (putative) chitin-binding domains; residues conserved in at least three of the sequences are printed in bold face, and additional residues conserved between $\mathrm{ChiA}$ and $\mathrm{ChiB}$ are underlined. References: 1, Brurberg et al., 1994; 2, Brurberg et al., 1995; 3, Watanabe et al., 1990b; 4, Watanabe et al., 1992; 5, unpublished results of M. Arai, as presented by Watanabe et al. (1994).

bears some resemblance to a chitin-binding domain identified in Bacillus circulans chitinase A1 (Fig. 5a, b). ChiA was hitherto considered to consist of a signal sequence, an $\mathrm{N}$-terminal domain with no clear similarities to other chitinases, and a catalytic domain (Watanabe $e t$ al., 1993; Blaak et al., 1993). After recent corrections in the sequence (Brurberg et al., 1994) and the elucidation of the three-dimensional structure (Perrakis et al., 1994) the domain composition of ChiA can now be updated. Firstly, the $\mathrm{N}$-terminal domain of the mature protein is structurally similar to a fibronectin type III-like domain (Fig. $5 \mathrm{a}$; Perrakis et al., 1994). Secondly, the recent corrections in the ChiA sequence (Brurberg et al., 1994; Perrakis et al., 1994) revealed that the enzyme contains a stretch of residues showing similarity to the $\mathrm{C}$-terminal domain of $\mathrm{ChiB}$ and to the chitin-binding domain of $B$. circulans chitinase A1 (Fig. 5b).

\section{DISCUSSION}

\section{General characteristics}

Purified ChiA and ChiB share several characteristics such as a broad $\mathrm{pH}$ optimum, a temperature optimum between 50 and $60^{\circ} \mathrm{C}$, and high stability. The less stable enzyme (ChiB) had the higher optimum temperature for activity. The optimum temperature for ChiB is probably underestimated since the enzyme is expected to undergo significant thermal inactivation at temperatures near $60^{\circ} \mathrm{C}$ within the time-scale of the activity assay. The activity of both $\mathrm{ChiA}$ and $\mathrm{ChiB}$ was unaffected by the presence of divalent metal ions $(10 \mathrm{mM})$ and by the presence of $\mathrm{NaCl}$ $(0-0.5 \mathrm{M})$. In summary, the results concerning activity and stability indicate that both enzymes are reasonably robust and active under a great variety of conditions. Inhibition of ChiA by its product $\left[(\mathrm{GlcNAc})_{2}\right]$ at concentrations around $1 \mathrm{mM}$ might limit the industrial applicability of this enzyme in some cases.

\section{Enzymic properties of ChiA}

Roberts \& Selitrennikoff (1988) showed that ChiA converts chitin into (GlcNAc) ${ }_{2}$ only. The enzyme also converted $p$-nitrophenyl- $\beta$-D- $N, N^{\prime}$-diacetylchitobioside [comparable to 4-MU-(GlcNAc) ${ }_{2}$ ] into the nitrophenyl group and (GlcNAc) $)_{2}$, which is considered to be characteristic for exo- $N, N^{\prime}$-diacetylchitobiohydrolases (Robbins et al., 1988; Tronsmo \& Harman, 1993). In the present study, these observations were only partly confirmed. In accordance with previous results, ChiA converted (GlcNAc) ${ }_{4}$ and $(\mathrm{GlcNAc})_{6}$ into (GlcNAc) ${ }_{2}$ only. However, noticeable amounts of GlcNAc were produced upon incubation of ChiA with colloidal chitin, indicating that ChiA possesses a second activity, for example that of an endochitinase. Endochitinolytic cleavages would result in the production of shorter GlcNAc oligomers that can be converted into mixtures of (GlcNAc) and GlcNAc. Alternatively, the production of GlcNAc from chitin might indicate the capability to cleave off (GlcNAc) [subsequently converted into (GlcNAc) ${ }_{2}$ and $\mathrm{GlcNAc}$ ] from the chitin chains by an exo-type action (exo$N, N^{\prime}, N^{\prime \prime}$-triacetylchitotriohydrolase). Activities similar to the latter have been suggested for a Clostridium stercorarium exoglucanase (Bronnenmeier et al., 1991) and for a human chitinase (Renkema et al., 1995).

The second activity (endochitinase or exo- $N, N^{\prime}, N^{\prime \prime}$ triacetylchitotriohydrolase) of ChiA is not reflected by the presence of detectable levels of trimers or monomers in the partial and full digests of (GlcNAc) ${ }_{6}$. An explanation for this might be that the substrate-binding site of ChiA can bind up to six GlcNAc moieties and that the catalytic centre is positioned between the fourth and the fifth GlcNAc binding-site (counted from the reducing end of a hexamer substrate; Perrakis et al., 1994). Thus, substrates containing six or less sugar units can bind to the active site with all their GlcNAc moieties, meaning that it is unlikely that oligomers longer than (GlcNAc) 2 are cleaved off from the non-reducing end. The extended active site in ChiA (which is a monomeric enzyme; Perrakis et al., 1994) might permit the simultaneous binding of two or more 4MU-(GlcNAc) ${ }_{2}$ molecules, which is a possible explanation for the cooperative kinetics observed with this substrate.

The fact that ChiA is capable of cleaving off 4-MU from 4MU-(GlcNAc) ${ }_{3}$ could be interpreted as a confirmation of its endochitinase or exo- $N, N^{\prime}, N^{\prime \prime}$-triacetylchitotriohydrolase activity (Robbins et al., 1988; Tronsmo \& Harman, 1993). It is puzzling, however, that almost no cleavage into 4-MU-GlcNAc + $(\mathrm{GlcNAc})_{2}$ occurs, where- 
as the natural substrate $(\mathrm{GlcNAc})_{4}$ is converted into (GlcNAc) $)_{2}$ only. Furthermore, $4-\mathrm{MU}$ is produced at approximately the same rate as when $4-\mathrm{MU}-(\mathrm{GlcNAc})_{2}$ is used as a substrate, which contrasts with the observation that ChiA primarily produces (GlcNAc) ${ }_{2}$ and not $(\mathrm{GlcNAc})_{3}$. These conflicting observations indicate that the cleavage rates and patterns obtained with the artificial 4-MU-chito-oligosaccharides do not (or only partly) reflect the real action of the chitinases on chitin and (GlcNAc) ${ }_{n}$ (see also Robbins et al., 1988; Watanabe et al., 1990a; Takayanagi et al., 1991). Nevertheless, comparisons of the cleavage rates of various 4-MU substrates are still used to characterize the catalytic activity of chitinases (Tronsmo \& Harman, 1993; Renkema et al., 1995).

The presence of an extended substrate binding site suggests that ChiA is optimized for the degradation of longer chito-oligosaccharides and chitin. This is supported by the presence of the $\mathrm{N}$-terminal fibronectin type III-like domain in ChiA that is known to have a positive effect on the activity of chitinases towards chitin (Watanabe et al., 1994). Furthermore, ChiA possesses a region sharing some similarity with part of the chitinbinding domain identified in $B$. circulans chitinase A1 (Watanabe et al., 1994; Fig. 5).

\section{Enzymic properties of ChiB and comparison with ChiA}

ChiB was found to be similar to ChiA in that its main product was (GlcNAc) ${ }_{2}$ for all natural substrates tested. In the case of $\mathrm{ChiB}$, in contrast to ChiA, the endochitinase or exo- $N, N^{\prime}, N^{\prime \prime}$-triacetylchitotriohydrolase activity that causes the formation of monomers in the reaction with chitin was confirmed by the detection of (GlcNAc) ${ }_{3}$ and GlcNAc as products of the reaction with (GlcNAc) ${ }_{6}$. It is tempting to speculate that the substrate-binding site of $\mathrm{ChiB}$ is designed to bind less than six GlcNAc moieties. This could explain why the endochitinase or exo$N, N^{\prime}, N^{\prime \prime}$-triacetylchitotriohydrolase activity of ChiB is detectable in the reaction with (GlcNAc) ${ }_{6}$. Several other results support the notion that $\mathrm{ChiB}$ possesses a less extended substrate-binding site than ChiA and, consequently, that $\mathrm{ChiB}$ may be optimized for cleavage of relatively short chito-oligosaccharides. First, $\mathrm{ChiB}$ has a lower specific activity towards chitin than $\mathrm{ChiA}$ and it does not contain a fibronectin type III-like domain as does ChiA. Second, ChiB does not exhibit the cooperative kinetics that were observed for ChiA. Finally, ChiB seems to have a higher affinity for the (GlcNAc) ${ }_{3}$ analogue than ChiA: whereas ChiB has a $K_{\mathrm{m}}$ of $34.1 \mu \mathrm{M}$ for $4-\mathrm{MU}$ $(\mathrm{GlcNAc})_{2}$, the $[\mathrm{S}]_{0.5}$ of ChiA for $4-\mathrm{MU}-(\mathrm{GlcNAc})_{2}$ was about $100 \mu \mathrm{M}$. Vorgias et al. (1993), determined the $K_{\mathrm{m}}$ of ChiA for another (GlcNAc) $)_{3}$ analogue to be as high as $500 \mu \mathrm{M}$. However, in the latter study, the problem of substrate inhibition (which is expected to occur: see above and Krishnan et al., 1994) was not addressed.

Analysis of the breakdown products of chitin did not reveal differences between ChiA and ChiB. This is likely to be due to the fact that only minor, undetectable amounts of products other than GlcNAc and (GlcNAc) accumulate during chitin degradation. Likewise, and possibly for the same reason, no differences in the ratio between reducing sugar formation and degradation rate were found. Furthermore, the reducing sugar assay may provide artificial results since the signal obtained per reducing group increases with the length of the chitooligosaccharides (Imoto \& Yagishita, 1971; M. B. Brurberg, unpublished observations). The observation that combining $\mathrm{ChiA}$ and $\mathrm{ChiB}$ results in synergistic effects on the rate of chitin degradation clearly shows that the enzymes not only differ in terms of their specific activity but also in terms of the mechanism by which they degrade the substrate. An obvious explanation for the synergy would be that one of the enzymes, by exerting an endochitinase activity, increases the substrate availability for the other enzyme, which has an exo- $N, N^{\prime}, N^{\prime \prime}$ triacetylchitotriohydrolase activity.

To permit a more detailed analysis of the differences between $\mathrm{ChiA}$ and $\mathrm{ChiB}$, we are currently conducting $\mathrm{X}$ ray crystallographic studies of $\mathrm{ChiB}$ prepared using the purification protocol described in this report. The availability of the ChiB structure would permit a structural comparison which ChiA (Perrakis et al., 1994) which might shed new light on the function of these enzymes and could provide a structural explanation for the differences between them [see Davies \& Henrissat (1995) for a review of existing structures of glycosyl hydrolases].

\section{The role of ChiA and ChiB in chitin breakdown}

The analyses described above show both similarities and differences in the enzymic properties of ChiA and ChiB. Both enzymes seem to have exo- $N, N^{\prime}$ diacetylchitobiohydrolase activity, combined with either an endochitinase or an exo- $N, N^{\prime}, N^{\prime \prime}$-triacetylchitotriohydrolase activity. In $S$. marcescens ChiA is located extracellularly (Brurberg et al., 1994) and therefore is likely to be optimized for degrading chitin and the longer GlcNAc oligomers, as suggested above. Considering its location, the presence of domains known to be important for chitin degradation, its extended substrate-binding site, and its high specific activity towards chitin (as compared to $\mathrm{ChiB}$ ), ChiA is likely to possess an endochitinase activity in addition to its exo- $N, N^{\prime}$-diacetylchitobiohydrolase activity. Consequently, ChiB's second activity is expected to be that of an exo- $N, N^{\prime}, N^{\prime \prime}$-triacetylchitotriohydrolase. ChiB has been found in the supernatant of late-stationary cultures of $S$. marcescens (Roberts \& Cabib, 1982; Fuchs et al., 1986), but analysis of the localization of $\mathrm{ChiB}$ in exponential and early-stationary cultures of $S$. marcescens has shown that this enzyme is almost exclusively directed towards the periplasm (without being processed; Brurberg et al., 1995). Thus it would seem that the role of $\mathrm{ChiB}$ in vivo is to digest the shorter GlcNAc oligomers capable of entering the periplasm, in accordance with the suggestions described above. The deduction that $\mathrm{ChiA}$ and $\mathrm{ChiB}$ possess an endochitinase and an exo- $N, N^{\prime}, N^{\prime \prime}$-triacetylchitotriohydrolase activity, 
respectively, is supported by preliminary results of studies on the degradation of chitin by mixtures of ChiA or $\mathrm{ChiB}$ and an endochitinase isolated from the fungus Trichoderma barzianum (Tronsmo \& Harman, 1993; M. B. Brurberg \& A. Tronsmo, unpublished results). These studies showed no synergistic effects on chitin breakdown upon combining ChiA with the endochitinase, whereas clear synergy was observed upon combining $\mathrm{ChiB}$ with the endochitinase.

A third chitinolytic enzyme of $S$. marcescens, an $\mathrm{N}$-acetyl$\beta$-glucosaminidase, has been described by Kless et al. (1989) and Vorgias et al. (1993). This enzyme is probably located in the periplasm (Kless et al., 1989) where its obvious role would be to convert the chitobiose produced by $\mathrm{ChiA}$ and $\mathrm{ChiB}$ into GlcNAc monomers. From the present study it seems that an enzymic apparatus consisting of $\mathrm{ChiA}$, ChiB and an $N$-acetyl $\beta$-glucosaminidase could be enough for effective in vivo degradation of chitin.

\section{ACKNOWLEDGEMENTS}

We thank Anne-May Lønneborg for technical assistance and Arne Tronsmo for supplying us with colloidal chitin. We are grateful to Per Nissen and Juke Lolkema for valuable discussions. This work was supported by a grant from the Norwegian Research Council.

\section{REFERENCES}

Blaak, H., Schnellmann, J., Walter, S., Henrissat, B. \& Schrempf, H. (1993). Characteristics of an exochitinase from Streptomyces olivaceoviridis, its corresponding gene, putative domains and relationship to other chitinases. Eur J Biochem 214, 659-669.

Bork, P. \& Doolittle, R. F. (1992). Proposed acquisition of an animal protein domain by bacteria. Proc Natl Acad Sci US A 89, 8990-8994.

Bronnenmeier, K., Rücknagel, K. P. \& Staudenbauer, W. L. (1991). Purification and properties of a novel type of exo-1,4- $\beta$-glucanase (Avicellase II) from the cellulolytic Clostridium stercorarium. Eur J Biocbem 200, 379-385.

Bradford, M. M. (1976). A rapid and sensitive method for the quantitation of protein utilizing the principle of protein-dye binding. Anal Biochem 72, 248-254.

Brurberg, M. B., Eijsink, V. G. H. \& Nes, I. F. (1994). Characterization of a chitinase gene (chiA) from Serratia marcescens strain BJL200 and one-step purification of the gene product. FEMS Microbiol Lett 124, 399-404

Brurberg, M. B., Eijsink, V. G. H., Haandrikman, A. J., Venema, G. \& Nes, I. F. (1995). Chitinase B from Serratia marcescens BJL200 is exported to the periplasm without processing. Microbiology 141, 123-131.

Cleland, W. W. (1963). Computer programmes for processing enzyme kinetic data. Nature 198, 463-465.

Davies, G. \& Henrissat, B. (1995). Structures and mechanisms of glycosyl hydrolases. Structure 3, 853-859.

Davis, B. \& Eveleigh, D. E. (1984). Chitosanases: occurrence, production and immobilization. In Chitin, Chitosan, and Related Enzymes, pp. 161-179. Edited by J. P. Zikakis. London: Academic Press.

De la Cruz, J., Hidalgo-Gallego, A., Lora, J. M., Benitez, T., PintorToro, J. \& Llobell, A. (1992). Isolation and characterization of three chitinases from Trichoderma barzianum. Eur J Biochem 206, 859-867.
Fuchs, R. L., McPherson, S. A. \& Drahos, D. J. (1986). Cloning of a Serratia marcescens gene encoding chitinase. Appl Environ Microbiol 51, 504-509.

Gooday, G. W. (1990). Physiology of microbial degradation of chitin and chitosan. Biodegradation 1, 177-190.

Harpster, M. H. \& Dunsmuir, P. (1989). Nucleotide sequence of the chitinase B gene of $S$. marcescens QMB1466. Nucleic Acids Res 17, 5395.

Imoto, T. \& Yagishita, K. (1971). A simple activity measurement of lysozyme. Agr Biol Chem 35, 1154-1156.

John, M., Röhrig, H., Schmidt, J., Wieneke, U. \& Schell, J. (1993). Rbizobium NodB protein involved in nodulation signal synthesis is a chitooligosaccharide deacetylase. Proc Natl Acad Sci USA 90, 625-629.

Jones, J. D. G., Grady, K. L., Suslow, T. V. \& Bedbrook, J. R. (1986). Isolation and characterization of genes encoding two chitinase enzymes from Serratia marcescens. EMBO J 5, 467-473.

Kless, H., Sitrit, Y., Chet, H. \& Oppenheim, A. B. (1989). Cloning of the gene coding for the chitobiase of Serratia marcescens. Mol Gen Genet 217, 471-473.

Koo, J. C., Lim, C. O., Choi, Y. J., Kim, C. Y., Bahk, J. D., Lee, S. Y. \& Cho, M. J. (1993). Expression of bacterial chitinase in tobacco and enhanced resistance against phytopathogenic fungi. EMBL Database, Accession number L01455.

Krishnan, A., Nair, P. N. \& Jones, D. (1994). Isolation, cloning and characterization of new chitinase stored in active form in chitinlined venom reservoir. J Biol Chem 269, 20971-20976.

Kuranda, M. J. \& Robbins, P. W. (1987). Cloning and heterologous expression of glycosidase genes from Saccharomyces cerevisiae. Proc Natl Acad Sci US A 84, 2585-2589.

Laemmli, U. K. (1970). Cleavage of structural proteins during the assembly of the head of bacteriophage T4. Nature 227, 680-685.

Lorito, M., Peterbauer, C., Hayes, C. K. \& Harman, G. E. (1994). Synergistic interaction between fungal cell wall degrading enzymes and different antifungal compounds enhances inhibition of spore germination. Microbiology 140, 623-629.

Manoil, C. \& Beckwith, J. (1986). A genetic approach to analyzing membrane protein topology. Science 233, 1403-1408.

Monreal, J. \& Reese, E. (1969). The chitinase of Serratia marcescens. Can J Microbiol 15, 689-696.

Perrakis, A., Tews, I., Dauter, Z., Oppenheim, A. B., Chet, I., Wilson, K. S. \& Vorgias, C. E. (1994). Crystal structure of a bacterial chitinase at $2 \cdot 3 \AA$ resolution. Structure $2,1169-1180$.

Renkema, G. H., Boot, R. G., Muijsers, A. O., Donker-Koopman, W. E. \& Aerts, J. M. F. G. (1995). Purification and characterization of human chitotriosidase, a novel member of the chitinase family of proteins. J Biol Chem 270, 2198-2202.

Roberts, R. L. \& Cabib, E. (1982). Serratia marcescens chitinase: onestep purification and use for the determination of chitin. Anal Biochem 127, 402-412.

Roberts, W. K. \& Selitrennikoff, C. P. (1988). Plant and bacterial chitinases differ in antifungal activity. J Gen Microbiol 134, 169-176.

Robbins, P. W., Albright, C. \& Benfield, B. (1988). Cloning and expression of a Streptomyces plicatus chitinase (chitinase-63) in Escherichia coli. J Biol Chem 263, 443-447.

Schickler, H., Haran, S., Oppenheim, A. B. \& Chet, I. (1993). Cloned chitinases and their role in biological control of plant pathogenic fungi. In: Chitin Engymology, pp. 375-382. Edited by R. A. A. Muzzarelli. Ancona, Italy: European Chitin Society.

Segel, I. H. (1975). Enzyme kinetics: Behavior and Analysis of Rapid Equilibrium and Steady-state Envyme Systems. New York: John Wiley. 
Shapira, R., Ordentlich, A., Chet, I. \& Oppenheim, A. B. (1989). Control of plant diseases by chitinase expressed from cloned DNA in Escherichia coli. Phytopathology 79, 1246-1249.

Stoll, V. S. \& Blanchard, J. S. (1990). Buffers : principles and practice. Metbods Enzymol 182, 24-38.

Sundheim, L., Poplawsky, A. R. \& Ellingboe, A. H. (1988). Molecular cloning of two chitinase genes from Serratia marcescens and their expression in Pseudomonas species. Phys Mol Plant Pathol 33, 483-491.

Takayanagi, T., Sjisaka, K., Takiguchi, Y. \& Shimahara, K. (1991). Isolation and characterization of thermostable chitinases from Bacillus licheniformis X-7u. Biochim Biophys Acta 1078, 404-410.

Tronsmo, A. \& Harman, G. E. (1993). Detection and quantification of $N$-acetyl- $\beta$-D-glucosaminidase, chitobiase and endochitinase in solutions and on gels. Anal Biochem 208, 74-79.

Vessey, J. C. \& Pegg, G. F. (1973). Autolysis and chitinase production in cultures of Verticillium albo-atrum. Trans Br Mycol Soc 60, 133-143.

Vorgias, C. E., Tews, I., Perrakis, A., Wilson, K. S. \& Oppenheim, A. B. (1993). Purification and characterization of the recombinant chitin degrading enzymes, chitinase A and chitobiase from Serratia marcescens. In: Chitin Envymology, pp. 417-422. Edited by R. A. A. Muzzarelli. Ancona, Italy: European Chitin Society.

Walkley, J. W. \& Tillman, J. (1977). A simple thin-layer chromatographic technique for the separation of mono- and oligosaccharides. J Chromatogr 132, 172-174.
Watanabe, T., Oyanagi, W., Suzuki, K. \& Tanaka, H. (1990a). Chitinase system of Bacillus circulans WL-12 and importance of chitinase A1 in chitin degradation. $J$ Bacteriol 172, 4017-4022.

Watanabe, T., Suzuki, K., Oyanagi, W., Ohnishi, K. \& Tanaka, H. (1990b). Gene cloning of chitinase A1 from Bacillus circulans WL-12 revealed its evolutionary relationship to Serratia chitinase and to the type III homology units of fibronectin. $J$ Biol Chem 265, 15659-15665.

Watanabe, T., Oyanagi, W., Suzuki, K., Ohnishi, K. \& Tanaka, H. (1992). Structure of the gene encoding chitinase D of Bacillus circulans WL-12 and possible homology of the enzyme to other prokaryotic chitinases and class III plant chitinases. J Bacteriol 174, 408-414.

Watanabe, T., Kobori, K., Miyashita, K., Fujii, T., Sakai, H., Uchida, M. \& Tanaka, H. (1993). Identification of glutamic acid 204 and aspartic acid 200 in chitinase A1 of Bacillus circulans WL-12 as essential residues for chitinase activity. $J$ Biol Chem 268, 18567-18572.

Watanabe, T., Ito, Y., Yamada, T., Hashimoto, M., Sekine, S. \& Tanaka, H. (1994). The roles of the C-terminal domain and type III domains of chitinase A1 from Bacillus circulans WL-12 in chitin degradation. J Bacteriol 176, 4465-4472.

Received 19 October 1995; revised 1 February 1996; accepted 21 February 1996 